\title{
Variation in litter under individual tree crowns: Implications for scattered tree ecosystems
}

\author{
CHRIS MCELHINNY, * CHARLES LOWSON, BART SCHNEEMANN AND \\ CARLOS PACHÓN \\ Australian National University, College of Sciences, The Fenner School of Environment and Society, \\ Forestry Building 48, Linnaeus Way, Canberra, ACT 0200, Australia (Email: \\ chris.mcelhinny@anu.edu.au)
}

\begin{abstract}
In forest ecosystems litter is usually assessed in terms of the average amount produced by the canopy. In scattered tree ecosystems this approach is problematic because the canopy is discontinuous and the spatial arrangement of litter highly variable. We addressed this problem by quantifying the spatial variation in litter load and litter composition associated with individual trees in a Eucalyptus melliodora - Eucalyptus blakelyi woodland. Litter was sampled under crowns and in grassland adjacent to 10 E. blakelyi and 10 E. melliodora trees ranging in diameter at breast height (dbh) from 14 to $129 \mathrm{~cm}$. A total of $302 \mathrm{~L}$ samples were collected from these trees, at distances ranging from 0 to $42 \mathrm{~m}$ from main stem. The sampled litter loads ranged from 0.02 to $109.3 \mathrm{tha}^{-1}$ and were significantly higher under tree crowns than in grassland for litter and each component of litter (leaves, bark, fine twigs, coarse twigs). In particular, the mean litter load under tree crowns $\left(12.5 \mathrm{t} \mathrm{ha}^{-1}\right)$ was an order of magnitude higher than the mean litter load in grassland $\left(1.27 \mathrm{t} \mathrm{ha}^{-1}\right)$. There was a significant $(P=0.0103)$ positive relationship between mean litter load under the tree crown and $\mathrm{dbh}$, indicating larger trees produced more litter per unit area of ground than smaller trees. Generalized Linear Modelling produced highly significant $(P<0.0001)$ models predicting the spatial variation in litter load and litter composition in terms of distance from main stem and dbh. Our models demonstrate gradients in litter load and composition under tree crowns. These gradients were most pronounced for the large trees in our study. The disproportionate input of litter and variety of litter components associated with large trees in our study supports their keystone role in scattered tree ecosystems and highlights the need to maintain these structures in agricultural landscapes.
\end{abstract}

Key words: litter gradient, paddock tree, savanna, woodland, Yellow Box.

\section{INTRODUCTION}

Litter is downed dead plant material less than $10 \mathrm{~cm}$ in diameter, covering but not yet incorporated into the uppermost soil horizon. It is a key component of forest and woodland ecosystems, contributing to nutrient cycles and the provision of habitat and food resources for fauna at a range of trophic levels. The breakdown of litter releases nutrients stored in plants and is an important mechanism for maintaining soil nutrient levels (Bray \& Gorham 1964; Rogers \& Westman 1977; McIvor 2001; Wilson 2002; Sangha et al. 2006). Where decomposition is limited by environmental extremes such as high temperatures and low soil moisture, the litter layer can represent a major store of nutrients and a high proportion of the cycling fraction. For example, in eucalypt forests equilibrium litter loads can exceed $30 \mathrm{t} \mathrm{ha}^{-1}$ (Keith 1997).

${ }^{\star}$ Corresponding author.

Accepted for publication March 2009.
Accumulated litter provides habitat and food resources for micro and macro invertebrates which form the base of important food chains (Sangha et al. 2006). Collembola and Acarina species of invertebrates which feed on decomposing plant material have been shown to increase in abundance with development of the litter layer (Majer et al. 1997; Oliver et al. 2006). These detrivores support a diversity of predator invertebrates, including centipedes and spiders for which litter complexity is critical (Uetz 1990). For example, Martin and Major (2001) found that litter components in woodland were more diverse than in pasture and that this in part explained the increased abundance of wolf spiders Araneae in the woodland. The invertebrate fauna within the litter layer may in turn support higher order predators including bird, reptile and mammal fauna. For example, Smith et al. (1994) found litter cover was positively correlated with the richness of ground foraging bird species in eucalypt forests in NE NSW, Australia and Gilmore (1985) found the density of ground foraging birds was positively correlated with the dry weight of litter in 
eucalypt forests and woodlands in Victoria and Queensland, Australia. Similarly, cover and litter depth have been positively correlated with the abundance of reptiles (Brown \& Nelson 1993; Smith et al. 1996; Brown 2001) and ground mammals (Barnett et al. 1978; Newsome \& Catling 1979) in temperate eucalypt forests.

Litter is usually assessed in terms of the average amount of litter produced by the forest canopy. This can either be in terms of the average accumulated litter load under the canopy which is assumed to be in equilibrium with decomposition processes, or by measuring litterfall from the forest or woodland canopy, together with the average decomposition rate under the canopy (Rogers \& Westman 1977; Lamb 1985; Pook et al. 1997; Crockford \& Richardson 1998; Dutta \& Agrawal 2001; Turner \& Lambert 2002). While these approaches are sensible for forest ecosystems with relatively continuous and homogeneous canopies, they are unsuited to understanding litter production in scattered tree ecosystems. In these ecosystems the canopy is discontinuous and the spatial arrangement of litter is likely to be highly variable. In particular, the quantity and types of litter under trees will be different to where the trees are absent (Martin \& Major 2001). The litter loads under individual tree crowns is also likely to vary with the size of the tree and the distance from the main stem. For example, large trees are likely to support higher litter loads than small trees because of their deeper crowns and large bark shedding branches. Similarly, areas close to the main stem are likely to support higher litter loads than areas at the edge of the crown zone because the depth of crown and size of branches decreases with distance from main stem.

Despite the important ecological functions of litter and the keystone role of scattered trees (Manning et al. 2006) relatively few studies have quantified litter production and its spatial variation under individual tree crowns. Grigg and Mulligan (1999) found that accumulated litter load beneath canopies of Acacia salicina was strongly related to stem basal diameter $\left(r^{2}=0.59\right)$, but did not quantify spatial variation under individual crowns. Abu-Bredu et al. (1997) found that litter production by crowns in a young Chamaecyparis obtusa stand was strongly related to stem basal area $\left(r^{2}=\right.$ $0.81)$. However, the small size of the trees precluded any spatial analysis of litter production under individual crowns. Graham et al. (2004) quantified spatial variation in litter and soil nutrient concentrations under scattered paddock trees on the Northern Tablelands of NSW. While they found soil C and P increased close to the tree stem they did not relate this to litter production. Oliver et al. (2006) quantified the spatial variation in accumulated litter loads, but excluded tree size as an effect by sampling similar sized trees. No study has quantified accumulated loads for different litter components (bark, fine twigs, coarse twigs, leaves), or their spatial variation as a basis for understanding the different habitats produced by litter in scattered tree ecosystems.

In this paper we address some of these gaps in our understanding of scattered tree ecosystems by quantifying the spatial variation in litter under the crowns of different sized trees in a Eucalyptus melliodora [A. Cunn. ex Schau] - Eucalyptus blakelyi [Maiden] woodland. To do this we tested the following hypotheses:

- The types and quantities of litter produced under tree crowns are different to those in adjacent grassland;

- The average density of litter under a tree crown depends on stem size and tree species;

- In scattered tree ecosystems there is fine scale spatial variation in litter density which depends on distance from tree stem, stem size and tree species, and litter component.

- This fine scale spatial variation in litter components produces micro-environments which differ in their relative abundance of litter components.

\section{METHODS}

\section{Data collection}

The study was conducted at Goorooyarroo Nature Reserve in the Australian Capital Territory. This Reserve is approximately 700 ha in size, and contains one of the largest and least modified areas of E. mellidora - E. blakelyi woodland in the ACT region (ACT Department of Territory \& Municipal Services 2007). Grazing and collection of firewood ceased in 2004 when the site was declared a nature reserve. Goorooyarroo therefore provided a scattered tree/grassland matrix with a relatively intact litter layer. For example, McElhinny et al. (2006) recorded a mean litter load of $6.8 \mathrm{t} \mathrm{ha}^{-1}$ for a representative sample of 16 woodlands in the Southern Tablelands compared with $8.0 \mathrm{t} \mathrm{ha}^{-1}$ at Goorooyarroo.

A sample of twenty trees was chosen for litter measurements. The sample was stratified by species and diameter at breast height (dbh) and comprised 10 E. melliodora and 10 E. blakelyi trees spread evenly across a dbh range from $10 \mathrm{~cm}$ to $120 \mathrm{~cm}$. Only isolated trees with intact healthy crowns were included in the sample to ensure litter loads were not confounded by neighbouring trees or stochastic events such as insect attack or weather damage. All trees were located on flat to undulating terrain with a slope less than five degrees. Litter was collected in mid-winter (July, August) 2007; the time of year when litter loads are most stable because production and decomposition 
are at a minimum (Pook et al. 1997; McIvor 2001). For each sample tree two transects were established to collect litter at increasing distances from the tree stem. Transects were in the direction of the major and minor axes of the tree crown. These varied sufficiently to randomize sampling in relation to prevailing wind direction. On each transect at least six litter samples were taken, three under the tree crown and three in the grassland. Under the crown samples were taken every $2 \mathrm{~m}(0,2,4,6 \ldots)$ except where the distance from stem to crown edge was $<4 \mathrm{~m}$. For these crowns samples were taken every $1 \mathrm{~m}$. In the grassland, the distance between litter samples was increased geometrically to more efficiently sample litter at large distances from the tree stem. Litter was sampled at each transect point using a $50 \mathrm{~cm} \times 50 \mathrm{~cm}\left(0.25 \mathrm{~m}^{2}\right)$ quadrat. All dead plant material within the quadrat and less than $10 \mathrm{~cm}$ in diameter was collected and stored in paper bags. Samples were oven dried at $60^{\circ} \mathrm{C}$ until the sample weight was stable. Samples were then sorted into leaves, bark, fine twigs $<5 \mathrm{~mm}$ in diameter, coarse twigs $\geq 5 \mathrm{~mm}$ in diameter and 'other' - fruits, grass and unidentifiable fine organic material. The dry weight of each litter component was then recorded.

\section{Statistical analysis}

Three separate analyses were used: first, analysis of variance (ANOVA) compared the mean dry weights of litter and litter components under the crown of trees with the mean dry weights in the grassland. In the second analysis, Generalised Linear Modelling was used to model mean litter dry weight under the crown in terms of tree size ( $\mathrm{dbh}$ ) and species. The final analysis incorporated spatial variation and modelled the dry weight of litter and litter components in terms of dbh, distance from tree stem, tree species and the interactions of these variables. Modelling used least squares regression analysis, and was fitted with a guided backwards stepwise approach. Only significant $(P<0.05)$ effects were retained in the final models. All data analysis was performed with JMP 7 statistical software (SAS Institute Inc. 2007).

\section{RESULTS}

Litter was collected from $10 \mathrm{E}$. blakelyi and $10 \mathrm{E}$. melliodora trees. The $E$. blakelyi trees ranged from $14 \mathrm{~cm}$ to $104 \mathrm{~cm}$ dbh with a mean dbh of $59 \mathrm{~cm}$ and the E. melliodora trees ranged from $16 \mathrm{~cm}$ to $129 \mathrm{~cm}$ with a mean dbh of $72 \mathrm{~cm}$. A total of $302 \mathrm{~L}$ samples were collected from these trees, at distances ranging from $0 \mathrm{~m}$ to $42 \mathrm{~m}$ from tree stem. Of these samples 180 were located under the crowns of trees and 122 in the adjacent grassland. The sampled litter loads ranged from $0.02 \mathrm{t} \mathrm{ha}^{-1}$ to $109.3 \mathrm{tha}^{-1}$ with a mean of $8.0 \mathrm{t} \mathrm{ha}^{-1}$.

Mean litter loads were significantly higher under tree crowns than in grassland for total litter and all five components of litter (Fig. 1). In particular, the mean

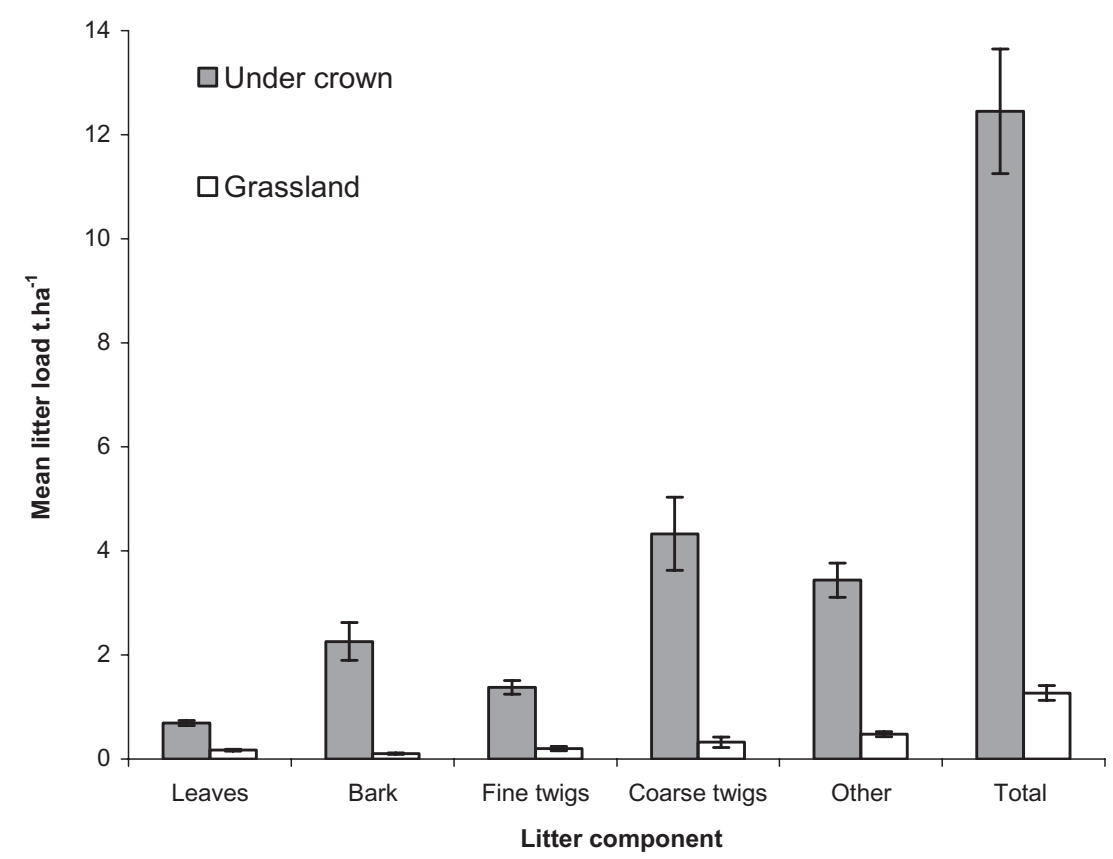

Fig. 1. Comparison of mean litter loads under tree crowns $(n=180)$ and in adjacent grassland $(n=122)$. For all litter components loads were significantly higher under tree crowns. 


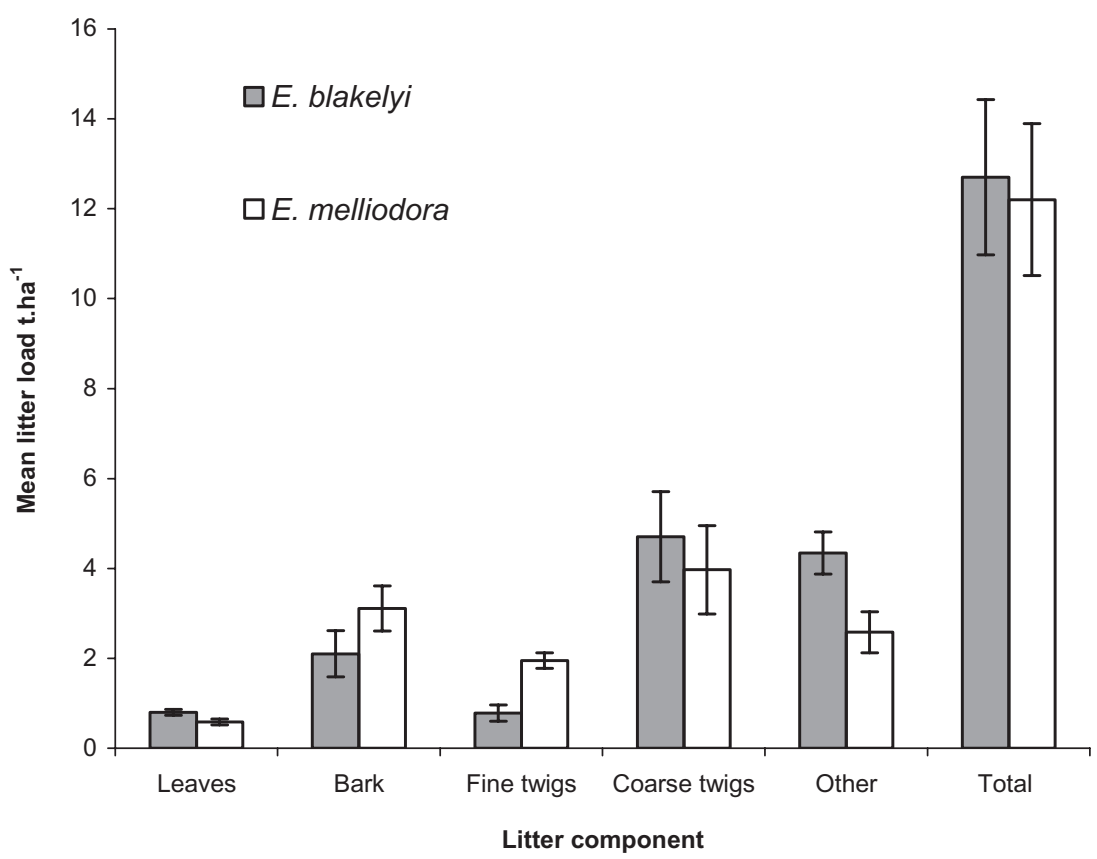

Fig. 2. Comparison of mean litter loads under E. blakelyi $(n=88)$ and E. melliodora $(n=92)$ tree crowns. There was no significant difference in total litter load between the two species, although there were significantly higher loads of leaf and other litter under E. blakelyi crowns and significantly more fine twig litter under E. melliodora crowns.

total litter load under tree crowns $\left(12.5 \mathrm{t} \mathrm{ha}^{-1}\right)$ was an order of magnitude higher than the mean total litter load in grassland $\left(1.27 \mathrm{t} \mathrm{ha}^{-1}\right)$. Comparison of means for the two tree species (Fig. 2) revealed no significant difference in total litter load between the two species, although there were significantly higher loads of leaf $(P=0.0251)$ and other $(P=0.0081)$ litter under $E$. blakelyi crowns and significantly more fine twig $(P<$ 0.0001) litter under E. melliodora crowns.

Generalized Linear Modelling was used to predict mean litter load under the tree crown in terms of tree size (dbh) and species. Species was not a significant effect in any of the models tested and so was removed from the analysis. For leaves, fine twigs and coarse twigs there was a weak positive relationship with tree $\mathrm{dbh}$, although no models were significant $(P>0.05)$. There was a strong positive relationship between dbh and bark, and dbh and total litter load. The model fitted for bark was highly significant and the model fitted for total litter load was significant (Fig. 3), indicating larger trees produced more litter per unit area of ground than smaller trees. The residuals for these models were approximately normally distributed with little heteroskedasticity. Models fitted in terms of tree basal area were also significant. However, the fit of these models was inferior to those in which tree dbh was the explanatory variable. For example, for total litter load, dbh $\left(r^{2}=0.31, P=0.01\right)$ was a better fit to the data than basal area $\left(r^{2}=0.27, P=0.02\right)$.

Multiple regression analysis was used to model the spatial variation in litter load and composition of litter load in terms of distance from tree stem and $\mathrm{dbh}$. Composition of litter was modelled in terms of the percentage of total litter load attributable to coarse (bark + coarse twigs) litter components. Distance and the weight of litter components were transformed using the square root and natural log functions to reduce variation in the raw data. To allow zero litter loads to be log transformed 0.1 was added to each litter component. We added 0.1 rather than 1 because of the small size of many of the litter loads. For each litter component, and the percentage of total litter load attributable to coarse components, the models that were fitted were highly significant $(P<0.0001)$ (Table 1$)$. No interaction terms were significant. The residuals for these models were approximately normally distributed with little heteroskedasticity. The fitted models were used to generate curves predicting the variation in litter load with distance from stem for small $(20 \mathrm{~cm} \mathrm{dbh})$, medium $(60 \mathrm{~cm} \mathrm{dbh})$ and large trees $(120 \mathrm{~cm} \mathrm{dbh})$. These curves indicated considerable spatial variation in litter loads under and adjacent to individual tree crowns (Figs 4,5). Predicted litter loads declined rapidly with distance from stem and large trees produced substantially higher loads than small trees. These gradients were strongest at close proximity to stems. The composition of litter also changed with distance from stem (Fig. 5b). Close to the main stem litter was largely composed of coarse material. As distance increased the contribution of fine components also increased. 

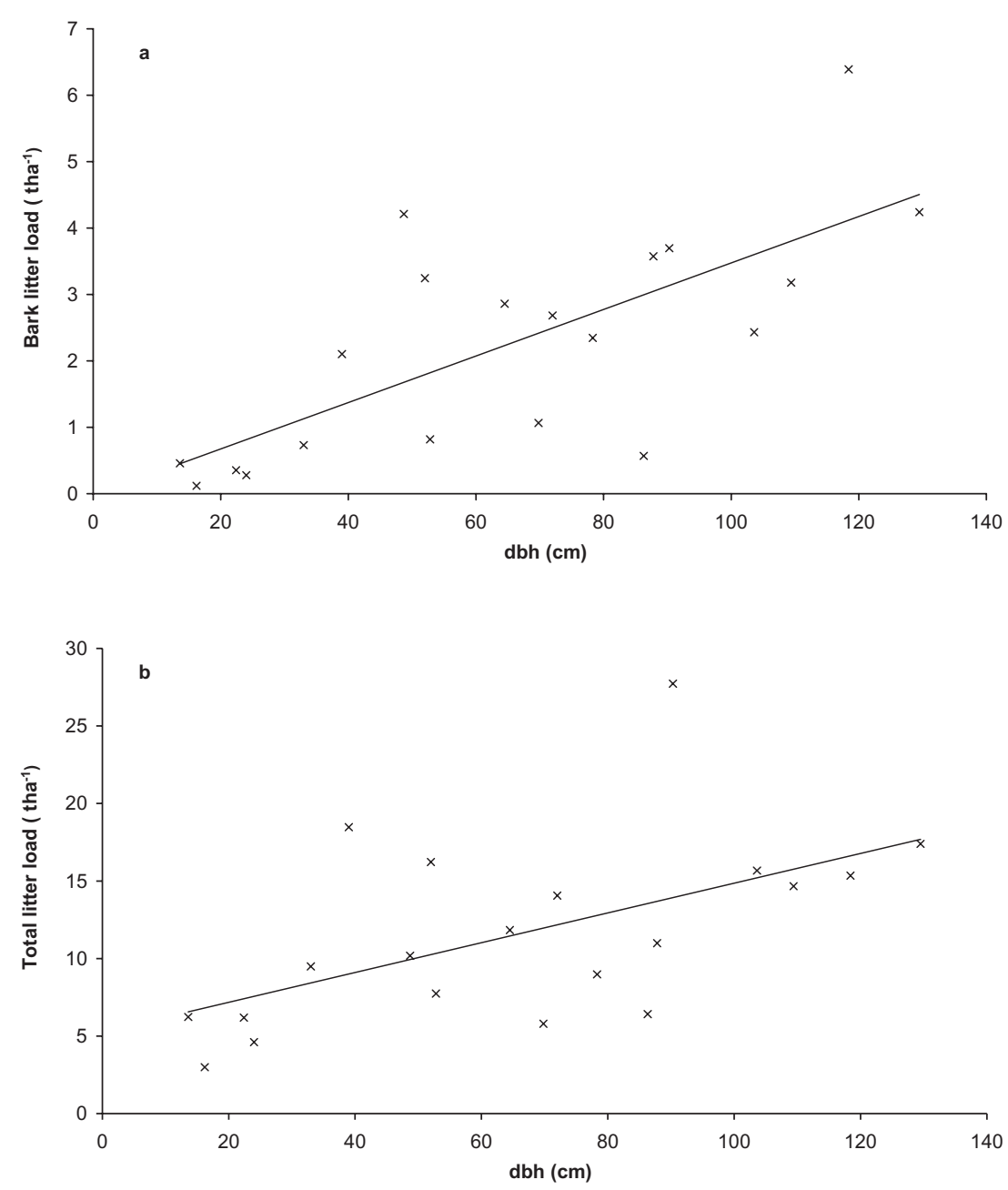

Fig. 3. Regression equations to predict mean litter load under crowns in terms of dbh. (a) Mean bark litter load $\left(\mathrm{t} \mathrm{ha} \mathrm{a}^{-1}\right)=$ $-0.026+0.035(\mathrm{dbh}), r^{2}=0.51, P=0.0004$. (b) Mean total litter load $\left(\mathrm{t} \mathrm{ha}^{-1}\right)=5.26+0.096(\mathrm{dbh}), r^{2}=0.31, P=0.0103$. dbh, diameter at breast height.

Table 1. Multiple regression models predicting accumulated load of different litter components ( $\left.t \mathrm{~h}^{-1}\right)$ and percentage of total litter load attributable to coarse (bark + coarse twigs) litter components in terms of tree diameter at breast height (dbh) (cm) and distance from main stem $(\mathrm{m})$

\begin{tabular}{llrl}
\hline Litter component & \multicolumn{1}{c}{ Regression model } & $R^{2}$ & $P$-value \\
\hline Leaves & $\ln ($ leaf litter +0.1$)=-0.45+0.0057(\mathrm{dbh})-0.32(\text { distance })^{0.5}$ & 0.38 & $<0.0001$ \\
Bark & $\ln ($ bark litter +0.1$)=-0.48+0.021(\mathrm{dbh})-0.86(\text { distance })^{0.5}$ & 0.70 & $<0.0001$ \\
Fine twigs & $\ln ($ fine twigs +0.1$)=-0.11+0.011(\mathrm{dbh})-0.55(\text { distance })^{0.5}$ & 0.51 & $<0.0001$ \\
Coarse twigs & $\ln ($ coarse twigs +0.1$)=0.21+0.019(\mathrm{dbh})-0.72(\text { distance })^{0.5}$ & 0.52 & $<0.0001$ \\
Total litter & $\ln \left(\right.$ total litter $=1.8+0.019(\mathrm{dbh})-0.79(\text { distance })^{0.5}$ & 0.72 & $<0.0001$ \\
\% coarse litter & \% coarse litter $=52+0.38(\mathrm{dbh})-9.9(\text { distance })^{0.5}$ & 0.34 & $<0.0001$ \\
\hline
\end{tabular}

No interaction terms were significant.

\section{DISCUSSION}

In this study the accumulated litter loads under tree crowns were very different to those in adjacent grassland. The environment under tree crowns on

(c) 2009 The Authors

Journal compilation (C) 2009 Ecological Society of Australia average accumulated an order of magnitude more litter mass per unit area of ground than grassland environments. This increased mass produced a more complex litter layer under tree crowns compared with grassland which other authors have also observed and 

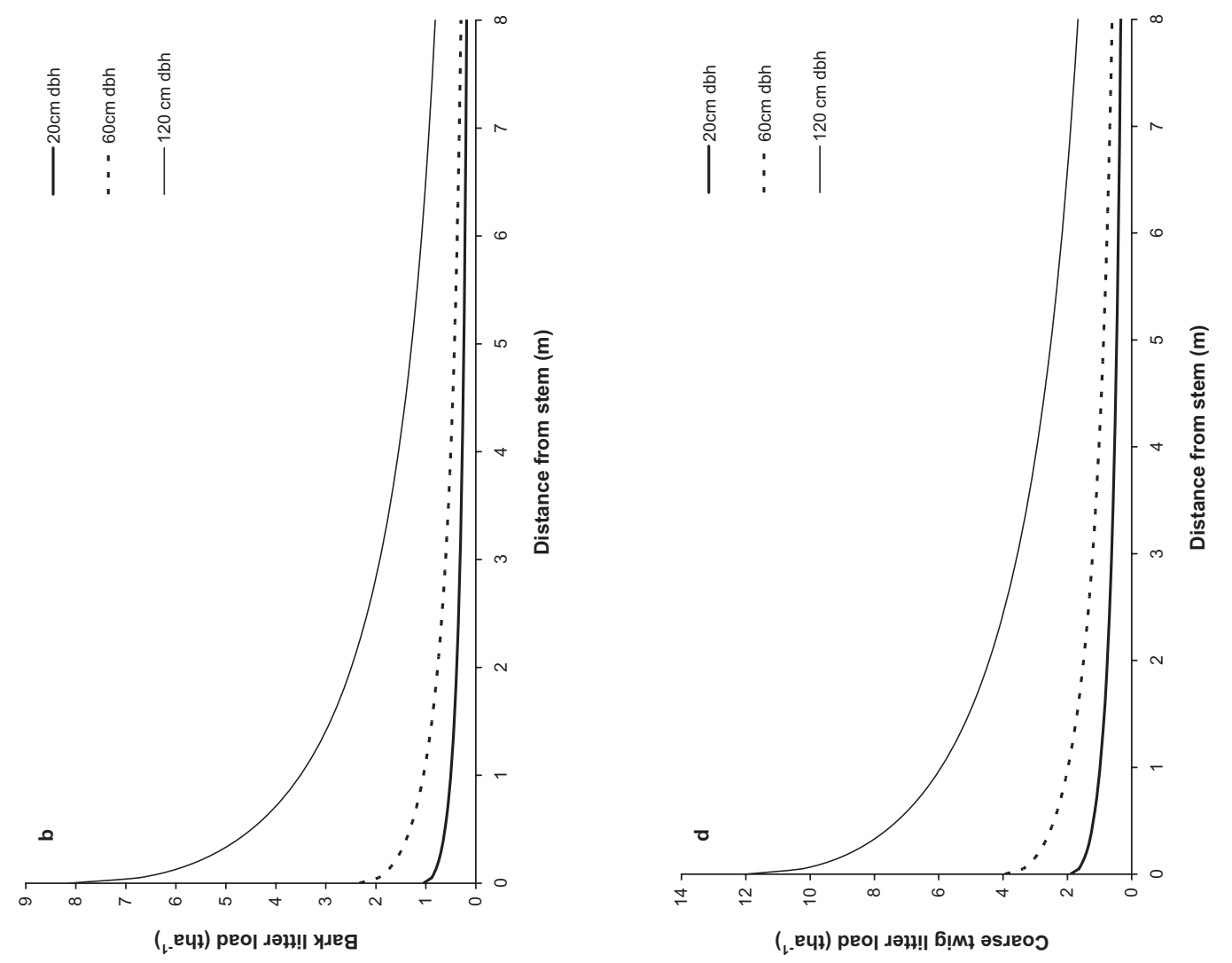

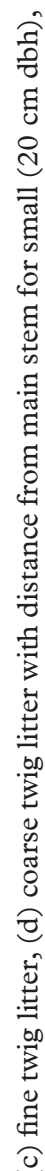

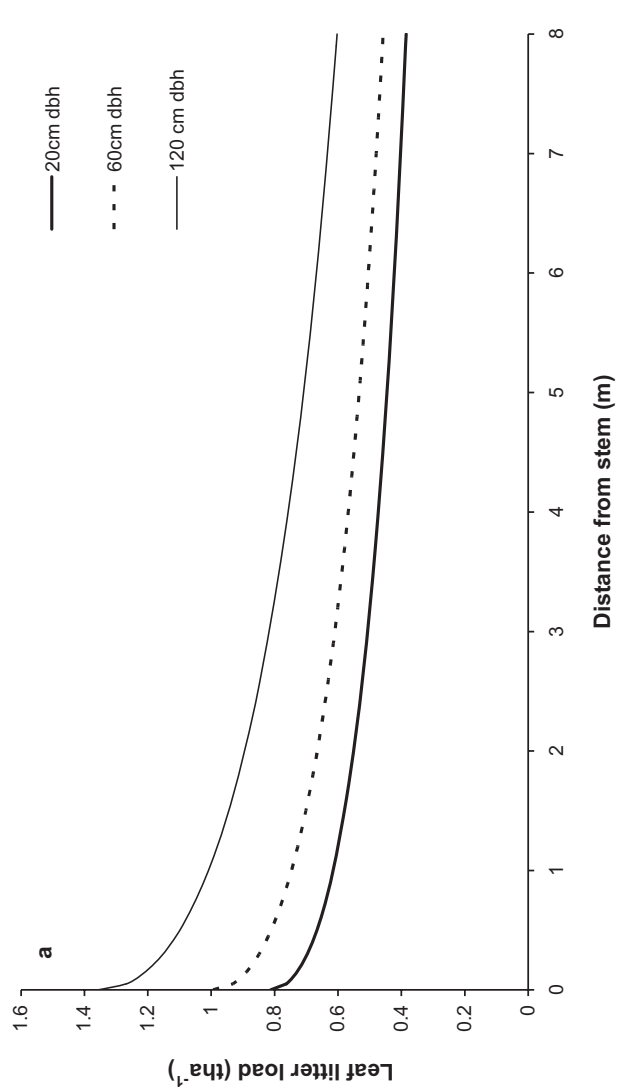

doi:10.1111/j.1442-9993.2009.02016.x

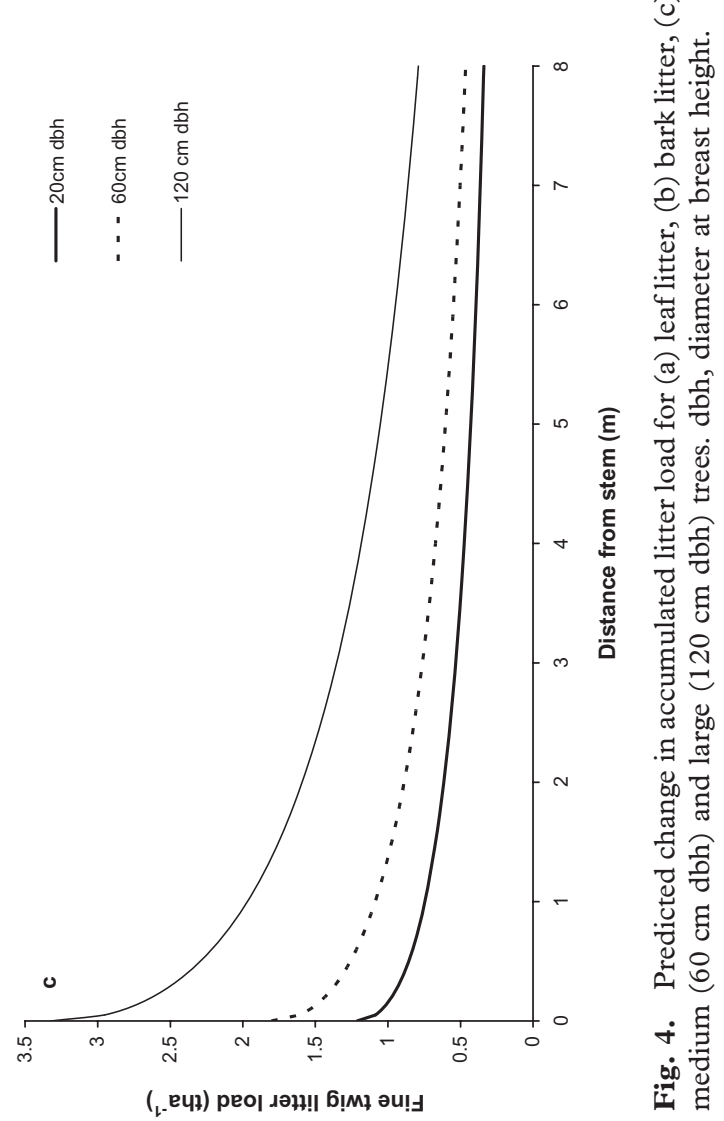

(C) 2009 The Authors

Journal compilation (C) 2009 Ecological Society of Australia 

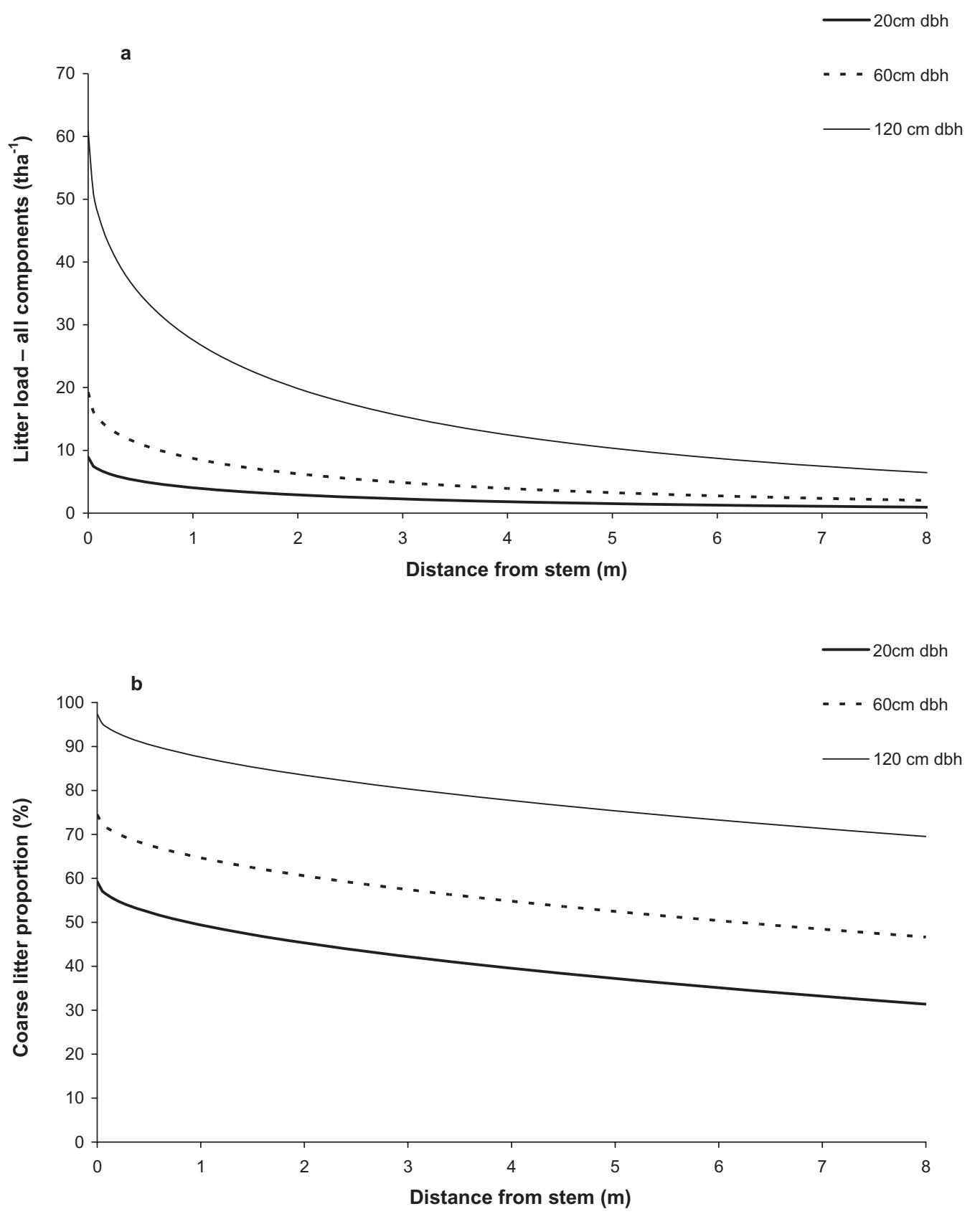

Fig. 5. Predicted change in litter load and composition with distance from main stem for small $(20 \mathrm{~cm}$ dbh), medium $(60 \mathrm{~cm}$ $\mathrm{dbh}$ ) and large $(120 \mathrm{~cm} \mathrm{dbh})$ trees. (a) Accumulated litter load (all components combined). (b) Percentage of total litter load attributable to coarse (bark + coarse twigs) litter components. dbh, diameter at breast height.

linked to increased invertebrate diversity (Martin \& Major 2001; Oliver et al. 2006). Our finding that mean litter load under crowns increased linearly with stem size was in agreement with previous studies (AbuBredu et al. 1997; Grigg \& Mulligan 1999). However, unlike Abu-Bredu et al. (1997), we found dbh was a better predictor of litter load than basal area. This makes sense in terms of simple crown architecture and the well established linear relationship between $\mathrm{dbh}$ and crown diameter for open grown trees (Lane-Poole 1936; Curtin 1970). If tree crowns are considered simple hemispherical shapes, then crown volume is proportional to (crown diameter) ${ }^{3}$. This volume sheds litter into the crown zone, an area proportional to (crown diameter) $^{2}$. Litter load will reflect the volume of crown per unit area of ground. This is crown volume divided by crown zone area and therefore proportional to crown diameter, and in turn dbh. We also found that 
the spatial arrangement of litter was heterogeneous under tree crowns, and followed a geometric gradient of decreasing accumulated load with distance from stem. Maximum litter loads occurred adjacent to the tree stem and then decreased rapidly. This was similar to the pattern observed by Oliver et al. (2006), although they correlated litter weight with the natural $\log$ of distance rather than the square root of distance, which we found was a better fit to our data. These patterns are also in keeping with the architecture of tree crowns in which the depth of crown contributing to litterfall is at a maximum directly above the main stem. Similarly the sectional area of branches is greatest at their connection with the main stem so that the surface area of branches shedding bark and twigs will also be greatest at this point (Zinke 1962).

The observed patterns of litter loads under isolated tree crowns may have important consequences for nutrient cycling and habitat in scattered tree ecosystems. The surface soils under tree crowns are likely to be higher in nutrients than soils in the adjacent grassland because of increased inputs from litter (e.g. Belsky 1994; Graham et al. 2004). Nutrients are also likely to follow a similar gradient to litter mass in relation to distance from stem. For example, Eldridge and Wong (2005) found surface soil concentrations of available P and exchangeable cations declined with distance from tree stem in the temperate box woodland they studied. In dry environments where water and nutrients are limited the root zones of scattered trees can extend well beyond their canopy edge into the adjacent grassland to access sufficient resources for growth. Litter inputs concentrate these additional nutrients in the crown zones of isolated trees increasing soil fertility compared with the adjacent grassland (Scholes 1990; Belsky et al. 1993; Joffre \& Rambal 1993).

The large litter mass under tree canopies is likely to increase the complexity of the litter layer and the range of habitats for invertebrates (Uetz 1979). This complexity is likely to be enhanced by the fine scale spatial variation we observed in litter loads. For example, our models predicted that a $120 \mathrm{~cm}$ dbh tree will support litter layers ranging from $60 \mathrm{tha}^{-1}$ near the stem, to less than $6 \mathrm{tha}^{-1}$ at the edge of the crown. The litter near the stem will also contain a higher proportion of bark and coarse twigs than litter at the edge of the crown. Our models therefore suggested a range of litter micro-environments and habitats under tree crowns reflecting changes in litter load and the relative abundance of fine and coarse material with distance from main stem. Our models also suggested these gradients will be most pronounced for large trees. We attribute this to the disproportionate amount of litter large trees contribute to the ecosystem compared with small trees. This reflects the combined effects of a linear increase in litter density with dbh with a geometric increase in the projected area under the tree crown with dbh. For example, a $120 \mathrm{~cm}$ dbh tree will have a projected crown area approximately 36 times that of a $20 \mathrm{~cm}$ dbh tree because crown diameter is proportional to dbh. Our models predicted that average litter density under the $120 \mathrm{~cm}$ dbh tree crown will be approximately two times that of the $20 \mathrm{~cm}$ dbh tree crown. Consequently, total litter accumulated under the $120 \mathrm{~cm}$ dbh tree will be in the order of 70 times that under the $20 \mathrm{~cm}$ dbh tree.

The disproportionate input of litter and the variety of litter components associated with the large trees in our study site supports their keystone role in scattered tree ecosystems as described by Manning et al. (2006), and highlights the need for strategies to maintain and regenerate paddock trees in agricultural landscapes (Gibbons \& Boak 2002).

\section{ACKNOWLEDGEMENTS}

We are grateful for advice and encouragement from Adrian Manning and Sandy Gilmore, technical assistance from Mauro Davanzo and logistic support from the Fenner School Undergraduate Independent Research Program. Comments from the Editor, Associate Editor and two anonymous referees improved an earlier version of this manuscript.

\section{REFERENCES}

Abu-Bredu S., Yokota T., Ogawa K. \& Hagihara A. (1997) Tree size dependence of litter production, and above-ground net production in a young Hinold (Chamaecyparis obtusa) Stand. F. For. Res. 2, 31-7.

ACT Department of Territory and Municipal Services (2007) Mulligans Flat and Goorooyarroo Nature Reserves. [Cited 12 March 2009.] Available from URL: http://www.tams.act. gov.au/_data/assets/pdf_file/0014/61034/ Mulligans_Flat_and_ Goorooyarroo_Brochure.pdf

Barnett J. L., How R. A. \& Humphreys W. F. (1978) The use of habitat components by small mammals in eastern Australia. Aust. F. Ecol. 3, 277-85.

Belsky A. J. (1994) Influences of trees on savanna productivity: tests of shade, nutrients, and tree-grass competition. Ecology 75, 922-32.

Belsky A. J., Mwonga S. M., Amundsun R. G., Duxbury J. M. \& Ali A. R. (1993) Comparative effects of isolated trees on their understorey environments in high- and low-rainfall savannas. F. Appl. Ecol. 30, 143-55.

Bray J. R. \& Gorham E. (1964) Litter production in forests of the world. Adv. Ecological. Res. 2, 101-57.

Brown G. W. (2001) The influence of habitat disturbance on reptiles in a Box-Ironbark eucalypt forest of south-eastern Australia. Biodiversity and Cons. 10, 161-76.

Brown G. W. \& Nelson J. L. (1993) Influence of successional stage of Eucalyptus regnans (mountain ash) on habitat use by reptiles in the Central Highlands, Victoria. Aust. F. Ecol. 18, 405-17. 
Crockford R. H. \& Richardson D. P. (1998) Litterfall, litter and associated chemistry in a dry sclerophyll eucalypt forest and a pine plantation in south-eastern Australia: 1. Litterfall and litter. Hydrol. Process. 12, 365-84.

Curtin R. (1970) Dynamics of Tree and Crown Structure in Eucalyptus obliqua. Forest Sci. 16, 321-8.

Dutta R. K. \& Agrawal M. (2001) Litterfall, litter decomposition and nutrient release in five exotic plant species planted on coal mine spoils. Pedobiologia 45, 298-312.

Eldridge D. J. \& Wong V. N. L. (2005) Clumped and isolated trees influence soil nutrient levels in an Australian temperate box woodland. Plant Soil 270, 331-42.

Gibbons P. \& Boak M. (2002) The value of paddock trees for regional conservation in an agricultural landscape. Ecological Management and Restoration 3, 205-10.

Gilmore A. M. (1985) The influence of vegetation structure on the density of insectivorous birds. In: Birds of Eucalypt Forests and Woodlands (eds A. Keast, H. F. Recher, H. Ford \& D. Saunders) pp. 21-31. Surrey Beatty \& Sons Pty Ltd, Chipping Norton.

Graham S., Wilson B. R., Reid N. \& Jones H. (2004) Scattered paddock tree, litter chemistry, and surface soil properties in pasture of the England Tablelands, New South Wales. Aust. f. Soil Res. 42, 905-12.

Grigg A. H. \& Mulligan D. R. (1999) Litterfall from two eucalypt woodlands in central Queensland. Aust. F. Ecol. 24, 662-4.

Joffre R. \& Rambal S. (1993) How tree cover influences the water balance of Meditteranean rangelands. Ecology 74, $570-82$.

Keith H. (1997) Nutrient cycling in eucalypt ecosystems. In: Eucalypt Ecology: Individuals to Ecosystems (eds J. E. Williams \& J. C. Z. Woinarski) pp. 197-226. Cambridge University Press, Cambridge.

Lamb R. J. (1985) Litterfall and nutrient turnover in two eucalypt woodlands. Aust. F. Bot. 33, 1-14.

Lane-Poole C. E. (1936) Crown ratio. Aust. Forestry 1, 5-11.

McElhinny C., Gibbons P. \& Brack C. (2006) An objective and quantitative methodology for constructing an index of stand structural complexity. Forest Ecol. Manag. 235, 54-71.

McIvor J. G. (2001) Litterfall from trees in semiarid woodlands of north-east Queensland. Austral Ecology 26, 150-5.

Majer J. D., Recher H. F., Wellington B. A., Woinarski J. C. Z. \& Yen A. L. (1997) Invertebrates of eucalypt formations. In: Eucalypt Ecology: Individuals to Ecosystems (eds J. E. Williams \& J. C. Z. Woinarski) pp. 278-302. Cambridge University Press, Cambridge.

Manning A. D., Fischer J. \& Lindenmayer D. B. (2006) Scattered trees are keystone structures - implications for conservation. Biol. Cons. 132, 311-21.
Martin T. J. \& Major R. E. (2001) Changes in wolf spider Araneae assemblages across woodland-pasture boundaries in the central wheatbelt of New South Wales, Australia. Austral Ecol. 26, 264-74.

Newsome A. E. \& Catling P. C. (1979) Habitat preferences of mammals inhabiting heathlands of warm temperate coastal, montane and alpine regions of southeastern australia. In: Ecosystems of the World 9A. Heathlands and Related Shrublands. Descriptive Studies (ed. R. L. Specht) pp. 30116. Elsevier, Amsterdam.

Oliver I., Pearce S., Greenslade P. J. M. \& Britton D. R. (2006) Contribution of paddock trees to the conservation of terrestrial invertebrate biodiversity within grazed native pastures. Austral Ecol. 31, 1-12.

Pook E. W., Gill A. M. \& Moore P. H. R. (1997) Long-term variation of litter fall, canopy leaf area and flowering in a Eucalyptus maculata forest on the south coast of New South Wales. Aust. F. Bot. 45, 737-55.

Rogers R.W. \& Westman W. E. (1977) Seasonal nutrient dynamics of litter in a subtropical eucalypt forest, North Stradbroke Island. Aust. F. Bot. 25, 47-58.

Sangha K. K., Jalota R. K. \& Midmore D. J. (2006) Litter production, decomposition and nutrient release in cleared and uncleared pasture systems of central Queensland, Australia. F. Trop. Ecology. 22, 177-89.

Scholes R. J. (1990) The influence of soil fertility on southern African Dry Savannas. F. Biogeographyraphy 17, 45-19.

Smith A. P., Andrews S. P. \& Moore D. M. (1994) Terrestrial Fauna of the Grafton and Casino State Forest Management Areas - Description and Assessment of Forestry Impacts Northern Region. State Forests of New South Wales, Pennant Hills.

Smith G. T., Arnold G. W., Sarre S., Abensperg-Traun M. \& Steven D. E. (1996) The effect of habitat fragmentation and livestock grazing on animal communities in remnants of gimlet Eucalyptus salubris woodland in the Western Australian wheatbelt. II. Lizards. F. Appl. Ecol. 33, 1302-10.

Turner J. \& Lambert M. J. (2002) Litterfall and forest floor dynamics in Eucalyptus pilularis forests. Austral Ecol. 27, 192-9.

Uetz G. W. (1990) Habitat structure and spider foraging. In: Habitat Structure: The Physical Arrangement of Objects in Space (eds S. S. Bell, E. D. McCoy \& H. R. Mushinsky) pp. 325-48. Chapman and Hall, London.

Uetz G.W. (1979) The influence of variation in litter habitats on spider communities. Oecologia 40, 29-42.

Wilson B. (2002) Influence of scattered paddock trees on surface soil properties: a study of the Northern Tablelands of NSW. Ecological Management and Restoration 3, 211-19.

Zinke P. J. (1962) The pattern of influence of individual forest trees on soil properties. Ecology 43, 130-3. 